\title{
Evaluation of Anti-Ulcer and Anti-Diarrhoeal Activities of the Ayurvedic Formulation Udumbara Ghanasatwa
}

\author{
N. MUDULI, A. BOSE* , C. DAS ${ }^{1}$, S. K. PRUSTY, S. MANDAL², D. DAS AND S. C. SI \\ School of Pharmaceutical Sciences, Siksha 'O' Anusandhan (Deemed to be University), Bhubaneswar, Odisha 751029, \\ ${ }^{1}$ Centurion University of Technology and Management, Bhubaneswar, Odisha 761211, ${ }^{2}$ Department of Pharmaceutical \\ Chemistry, Dr. B. C. Roy College of Pharmacy and AHS, Durgapur, West Bengal 713206, India
}

\section{Muduli et al.: Anti-Ulcer and Anti-Diarrhoeal Activities of Udumbara Ghanasatwa}

\begin{abstract}
Udumbara Ghanasatwa is a classical Ayurvedic formulation prescribed for the treatment of gastritis, indigestion and diarrhoea without any scientific validation of its pharmacological action. The present study investigated the antiulcer activity of Udumbara Ghanasatwa at two graded doses by pylorus ligation model in rats. The anti-diarrhoeal activity was also evaluated in terms of the defecation amount/frequency as well as intestinal fluid enteropooling in castor oil induced diarrhoea. The Ghanasatwa exerted significant protective effects in both pylorus ligation-induced gastric ulcer and castor oil induced diarrhoeal models in a dose-dependent manner. Findings obtained in the study justified the clinical applications of Udumbara Ghanasatwa in the treatment of gastric ulcers and diarrhoea. These pharmacological effects exerted by Ghanasatwa may be attributed to the antioxidant phytoconstituents like flavonoids and tannins present in it.
\end{abstract}

Key words: Ficus racemosa, Ghanasatwa, peptic ulcer, diarrhoea, antioxidant

Globally, diarrhoea and peptic ulcer are the two commonest gastrointestinal disorders faced by humans. The conventional synthetic medicines used in the management of these diseases are mainly symptomatic and do not cure the cause of the disease. Moreover, they cannot be administered for the long term due to their side effects. The World Health Organization (WHO) has also emphasized the use of traditional medicines in primary health care ${ }^{[1]}$.

Since ancient times, many indigenous drugs have been used in India as anti-diarrhoeal and anti-ulcer agents. Udumbara Ghanasatwa is one of such classical Ayurvedic formulations indicated in the treatment of gastritis, indigestion and diarrhoea ${ }^{[2]}$. It belongs to a special class of Ayurvedic dosage form called Ghanasatwa, which are made by thermally solidifying aqueous decoction of the herbal material to powder or tablet form. Udumbara Ghanasatwa is prepared from the root barks of Ficus racemosa (F. racemosa), which is one of the herbs mentioned in many ancient scriptures of Ayurveda, Siddha and Unani. Various parts of $F$. racemosa such as bark, root, leaf, fruits and latex are used as astringent, vermifuge, carminative and anti-dysenteric $^{[3]}$. Literature review revealed that there

*Address for correspondence

E-mail: anindyabose_in@yahoo.com

January-February 2022 is no reported work on pharmacological evaluation or quality standardization of Udumbara Ghanasatwa. This study investigates the anti-diarrhoeal and anti-ulcer potential of this product as well as reports some of its quality standardization parameters.

\section{MATERIALS AND METHODS}

\section{Collection and authentication:}

Root barks of the living $F$. racemosa were collected from Chandaka Industrial Estate, Odisha, India. They were authenticated by Dr. Debajyoyi Das, Head of Pharmacognosy Department, School of Pharmaceutical Sciences, Siksha O Anusandhan. The collected root barks were cleaned properly and dried under shade. The microscopic evaluation of root bark sections was performed by previously reported procedure and photographs at different magnifications were taken with Nikon Lab photo 2 microscopic units ${ }^{[4]}$.

This is an open access article distributed under the terms of the Creative Commons Attribution-NonCommercial-ShareAlike 3.0 License, which allows others to remix, tweak, and build upon the work non-commercially, as long as the author is credited and the new creations are licensed under the identical terms

Accepted 10 January 2022

Revised 06 August 2021

Received 01 May 2020

Indian J Pharm Sci 2022;84(1):49-57 


\section{Preparation and characterization:}

The cleaned root barks were spread evenly and shed dried for 10-15 $\mathrm{d}$. Then they were converted to churna (powder) as per the standard method of Ayurvedic Pharmacopoeia of India. Briefly, the dried plant material was powdered by grinding and passed through sieve no. 80 to get uniformly blended churna ${ }^{[5]}$. Powder microscopic analysis of the churna was carried out and characteristic features were observed by a Carl Zeiss binocular microscope attached with a camera ${ }^{[6]}$. The remaining portion of churna was stored in an airtight container for preparation of formulation.

For the preparation of Udumbara Ghanasatwa, one part of the prepared churna was mixed with four parts of water and kept overnight. Then it was subjected to a decoction process till it was reduced to onefourth quantity and filtered through a white cloth. The decoction was then concentrated by heating to semisolid consistency and thereafter it was dried in sunlight for $15 \mathrm{~d}$, powdered and preserved in an airtight glass bottle $^{[2]}$. Pharmacognostic characterization parameters such as organoleptic parameters (Appearance, colour, odour and taste), and qualitative phytochemical tests were carried out as per the standard methods ${ }^{[7]}$.

\section{Evaluation of antioxidant activity:}

Determination of total phenolic compounds: According to the standard protocol, $0.4 \mathrm{ml}$ of aqueous Ghanasatwa solution $(1 \mathrm{mg} / \mathrm{ml})$ was taken in a test tube and $1 \mathrm{ml}$ each of distilled water and Folin-Ciocalteu reagent were added. After $1 \mathrm{~min}$ shaking, $1.6 \mathrm{ml}$ of sodium carbonate solution ( $7.5 \%$ ) was added and the test tube was allowed to stand for $30 \mathrm{~min}$ with intermittent shaking. The absorbance was measured at $760 \mathrm{~nm}$ with a Ultraviolet (UV)/Visible spectrophotometer ${ }^{[8]}$. The estimation of the total phenol content was carried out in triplicate. The content of phenolic compounds was expressed as Gallic Acid Equivalents (GAE) per gram of Ghanasatwa (mg GAE/g) through the calibration curve of gallic acid $(10-100 \mu \mathrm{g} / \mathrm{ml})$.

Total flavonoids determination: In this estimation, $1 \mathrm{ml}$ of aqueous Ghanasatwa solutions $(1 \mathrm{mg} / \mathrm{ml})$ was added to a $10 \mathrm{ml}$ volumetric flask containing $4 \mathrm{ml}$ of distilled water and $0.30 \mathrm{ml}$ of $5 \%$ sodium nitrite solution was added. After $5 \mathrm{~min}$ of incubation, $0.3 \mathrm{ml}$ of $10 \%$ aluminium chloride was added and the mixture was allowed to stand for $5 \mathrm{~min}$, followed by the addition of $2 \mathrm{ml}$ of $1 \mathrm{M}$ sodium hydroxide. Subsequently, the volume was made up to $10 \mathrm{ml}$ with distilled water and the absorbance was measured against the blank at $510 \mathrm{~nm}$ with a UV/Visible spectrophotometer ${ }^{[9]}$. The total flavonoid content was expressed as mg Quercetin Equivalents (QE) per gram of Ghanasatwa (mg QE/g).

Estimation of total tannin content: As per the FolinCiocalteu method, $0.5 \mathrm{ml}$ of Folin phenol reagent and $7.5 \mathrm{ml}$ of distilled water were mixed with $0.1 \mathrm{ml}$ aqueous Ghanasatwa solution $(1 \mathrm{mg} / \mathrm{ml})$, followed by $1 \mathrm{ml}$ of $35 \%$ sodium carbonate solution. The mixture was diluted with distilled water up to $10 \mathrm{ml}$ and after vigorous shaking, it was kept at room temperature for $30 \mathrm{~min}$. The absorbance was measured against the blank at $700 \mathrm{~nm}$ with a UV/Visible spectrophotometer. The total tannin content was expressed in terms of mg of Tannic Acid Equivalents (TAE) per gram of Ghanasatwa (mg QE/g) $)^{[10]}$.

\section{2,2-Diphenyl-1-Picrylhydrazyl (DPPH) radical} scavenging activity method: In this method, $1 \mathrm{ml}$ of freshly prepared ethanolic DPPH solution $(0.1 \mathrm{mM})$ was added to $4 \mathrm{ml}$ of Ghanasatwa solutions (10-100 $\mu \mathrm{g} / \mathrm{ml})$, shaken properly and kept in the dark for $30 \mathrm{~min}$. The absorbance of these solutions was measured at $516 \mathrm{~nm}$ using a UV/Visible spectrophotometer ${ }^{[11]}$. The degree of discoloration in the sample mixtures indicated its free radical scavenging capacity. Quercetin was used as a standard antioxidant for comparison. The percentage of DPPH radical scavenging activity was measured by the following formula: $\left[\left(\mathrm{Abs}_{\text {control }}-\mathrm{Abs}_{\text {sample }}\right) / \mathrm{Abs}_{\text {control }}\right] \times 100$, where $\mathrm{Abs}_{\text {control }}$ and $\mathrm{Abs}_{\text {sample }}$ indicate absorbance of control and sample respectively.

\section{Evaluation of pharmacological activity:}

Animals: Swiss albino rats of either sex weighing around 150-180 g were used in the study. Animals were procured from the animal house from the School of Pharmaceutical Sciences, Siksha 'O' Anusandhan. They were kept in laboratory conditions for study. All experiments were carried out in the daytime between 10:00 a.m. to 05:00 p.m. All the experimental protocols were approved by the institutional ethics committee.

\section{Acute toxicity study:}

The acute toxicity of the Ghanasatwa was determined in rats of either sex as per Organisation for Economic Co-operation and Development (OECD) guidelines no. 425 (OECD, 1998). For this method, $100 \mathrm{mg} /$ $\mathrm{kg}$, orally (p.o.) was selected as starting dose while $2000 \mathrm{mg} / \mathrm{kg}$, p.o. was the highest dose. The animals after dosing were observed for $24 \mathrm{~h}$ with special emphasis during the first $4 \mathrm{~h}$. Observations change in behaviour 
and clinical signs including mortality ${ }^{[12]}$.

\section{Evaluation of anti-ulcer activity by pylorus ligated model:}

Rats fasted for $18 \mathrm{~h}$ were divided randomly into four groups of five each and dosing was done. The first group (control) received only vehicle (distilled water), while the second group of animals was administered with the standard drug ranitidine $(100 \mathrm{mg} / \mathrm{kg}$, p.o.). The third and fourth groups were orally administered with the Ghanasatwa solution at the dose levels of $200 \mathrm{mg} / \mathrm{kg}$ and $400 \mathrm{mg} / \mathrm{kg}$, respectively. After $1 \mathrm{~h}$, each animal was anesthetized, the abdomen was opened by a small midline incision below the xiphoid process and pyloric ligation was done. The stomach was replaced immediately and the abdomen was closed by interrupted sutures. After $4 \mathrm{~h}$ of pyloric ligation rats were sacrificed, the abdomen was opened. The volume of the gastric juice, $\mathrm{pH}$, total and free acidity was measured. The inner surfaces of the free stomach of rats were cut opened and the severity of haemorrhagic erosions in the acid-secreting mucosa was assessed on a scale of 0 to $3(0=$ Normal coloured stomach, $0.5=$ Red colouration, $1=$ Spot ulcer, $1.5=$ Hemorrhagic streaks, $2=$ Ulcers $\geq 3$ but $\leq 5,3=$ ulcers $>5)^{[13]}$. The sum of all scores in each stomach was used as the lesion index ${ }^{[14]}$.

\section{Evaluation of anti-diarrhoeal activity:}

In the castor oil-induced diarrhoea model, rats fasted for $18 \mathrm{~h}$ were divided randomly into four groups containing five in each. At the start of experimentation, the first group of animals was administered orally only with normal saline solution ( $5 \mathrm{ml} / \mathrm{kg}$, p.o.). The second group received the standard drug loperamide $(3 \mathrm{mg} / \mathrm{kg}$, p.o.). The third and fourth groups were treated with two different dosages of Ghanasatwa (200 and $400 \mathrm{mg} / \mathrm{kg}$ p.o). After $1 \mathrm{~h}$, all the animals received $1 \mathrm{ml}$ of castor oil orally. Thereafter, the animals were placed in cages lined with adsorbent papers and observed for $4 \mathrm{~h}$ for the presence of characteristic diarrhoeal droppings. The percent (\%) inhibition of defecation was measured using the following formula: $[(\mathrm{A}-\mathrm{B}) / \mathrm{A}] \times 100$, where $\mathrm{A}$ is the mean number of defecations caused by castor oil and $\mathrm{B}$ is the mean number of defecations caused by the $\operatorname{drug}^{[12]}$.

In the castor oil-induced enteropooling method, the rats fasted for $18 \mathrm{~h}$ were divided randomly into four groups of five each. The dosing was done similarly to the castor oil induced diarrhoea model. Each animal was sacrificed after $30 \mathrm{~min}$ oral administration of $1 \mathrm{ml}$ castor oil and the small intestine was ligated both at the pyloric sphincter and the ileocaecal joints. The intestine was dissected, contents were collected into measuring cylinders and the volume of fluid was noted ${ }^{[12]}$.

\section{Statistical analysis:}

All the measurements of in vitro antioxidant studies were taken in triplicate and the results were expressed as mean \pm standard deviation. The results of anti-diarrhoeal and antiulcer studies in rats were analyzed by one-way Analysis of Variance (ANOVA) followed by a post hoc Tukey Honestly Significant Difference (HSD) test.

\section{RESULTS AND DISCUSSION}

Histological section of root bark of $F$. racemosa stained with hematoxylin and safranin is depicted in fig. 1. Photomicrographs of transverse sections were taken at different magnification i.e., 5x, 10x and 40x. The outermost cork region of the root is presented with a dark brownish color. The cortex region is occupied by 12-14 layers of parenchymatous cells at the upper part of the section encircling pericyclic fibers. These are the highly lignified sclerenchymatous cell, present in groups and surround the central region of the root, thus provide mechanical strength to the root. This region is followed by 9-12 thin rectangular layers of cambium. The central regions of the root are mostly covered by xylem vessels. These vessels are surrounded by xylem parenchyma and pericyclic fibers. Proto-xylems are concentrated at the center of the root and metaxylems are scattered towards the peripheral regions. As the proto and meta-xylem covers the central wide region of the root, thus pith is absent. Medullary rays of bi-multiseriate are directed from the central region to the peripheral region. Abundant starch grains are distinguished between the parenchymatous cells of the cortex region and rectangular cells of medullary rays. These starch grains are simple and spherical in nature.

Diagnostic powder characteristic of Udumbara churna revealed the presence of lignified and non-lignified phloem fibers, lignified pitted xylem vessels, fragments of cork and cortex, starch grains and prismatic calcium oxalate crystals (fig. 2).

The organoleptic parameters of Udumbara Ghanasatwa are reported in Table 1 . The preliminary phytochemical screening of Ghanasatwa revealed the presence of phytoconstituents like carbohydrates, alkaloids, glycoside, saponins and phenolic compounds like flavonoids and tannins. 


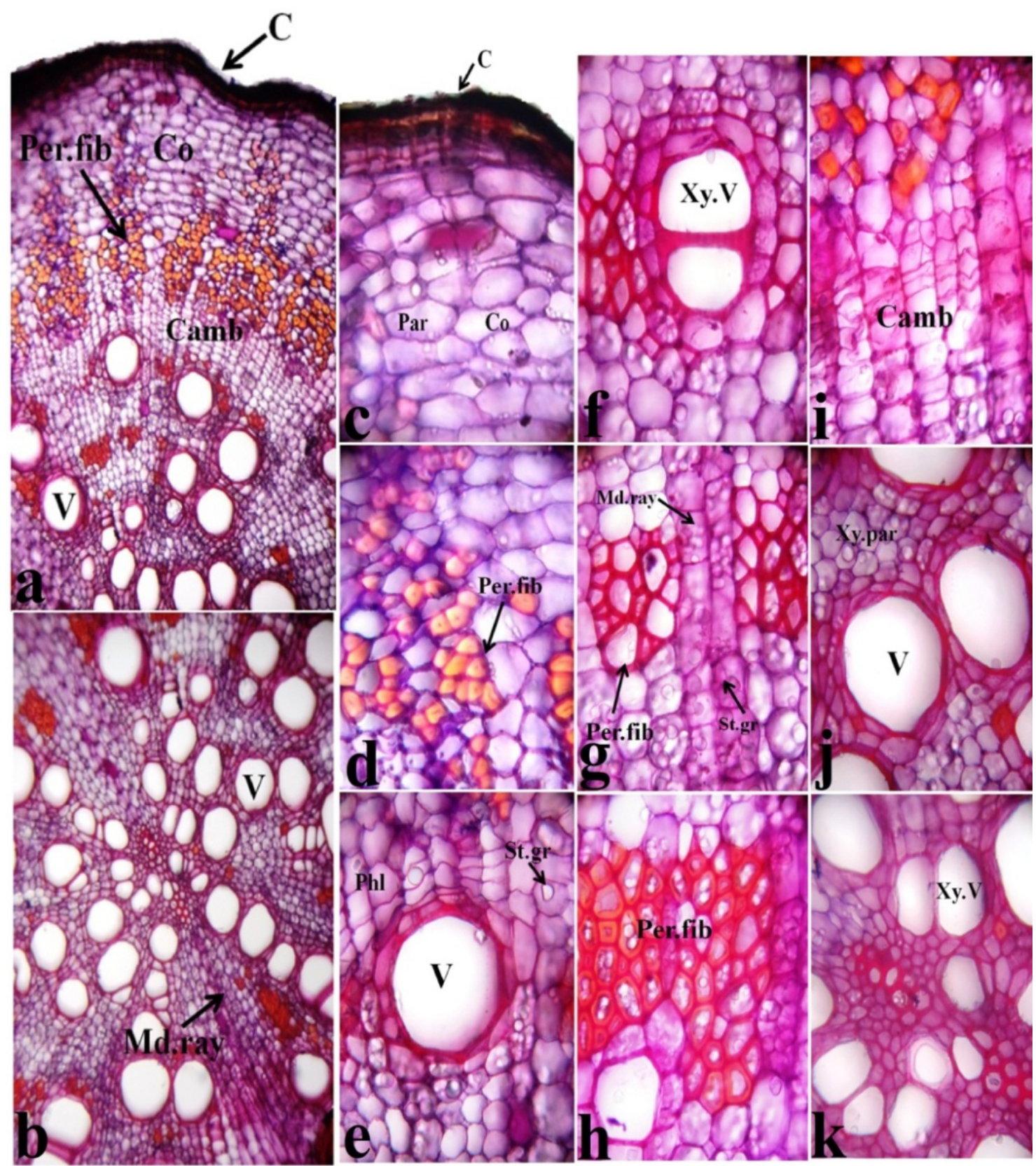

Fig. 1: (a, b) Transverse section of $\operatorname{root}(5 x, 5 x)$; (c) Enlarge portion of cork and cortex $(5 x, 40 x)$; (d, h) Enlarged portion of pericyclic fibre (5x, 40x); (e, f) Enlarged portion of vessel (5x, 40x); (g) Enlarge portion of medullary rays (5x, 40x); (i) Enlarged portion of cambium (5x, 40x); (j) Enlarged portion of vessel and xylem parenchyma (5x, 40x); (k) Enlarged portion of central part of root showing xylem vessels, xylem parenchyma and sclerenchymatous cells $(5 x, 40 x)$

The antioxidant activity of Ghanasatwa was estimated in terms of half-maximal inhibitory concentration $\left(\mathrm{IC}_{50}\right)$ of DPPH free radical scavenging at the concentration range of $10-100 \mu \mathrm{g} / \mathrm{ml}$. The Ghanasatwa scavenged the DPPH free radicals in a dose-dependent manner with the $\mathrm{IC}_{50}$ of $68.22 \mu \mathrm{g} / \mathrm{ml}$, while the corresponding $\mathrm{IC}_{50}$ of quercetin standard was found to be $2.75 \mu \mathrm{g} / \mathrm{ml}$.

The total phenolic content was determined using the gallic acid linear curve: $y=0.0076 x+0.0553\left(R^{2}=0.992\right)$.
The total phenolic content in Ghanasatwa was derived to be as good as $24.3 \pm 1.14 \mathrm{mg}$ GAE/g. Similarly, the total flavonoid $(\mathrm{mg} / \mathrm{ml})$ content was obtained using the quercetin calibration curve: $\mathrm{y}=0.0079 \mathrm{x}-0.0098$, $\mathrm{R}^{2}=0.9984$. The total flavonoid content of the Ghanasatwa was estimated to be low with a value of $2.09 \pm 0.17 \mathrm{mg}$ GAE/g. The tannic acid standard curve: $y=0.0005 x-0.011, R^{2}=0.9903$ was used for the estimation of total tannin content. It was found that 


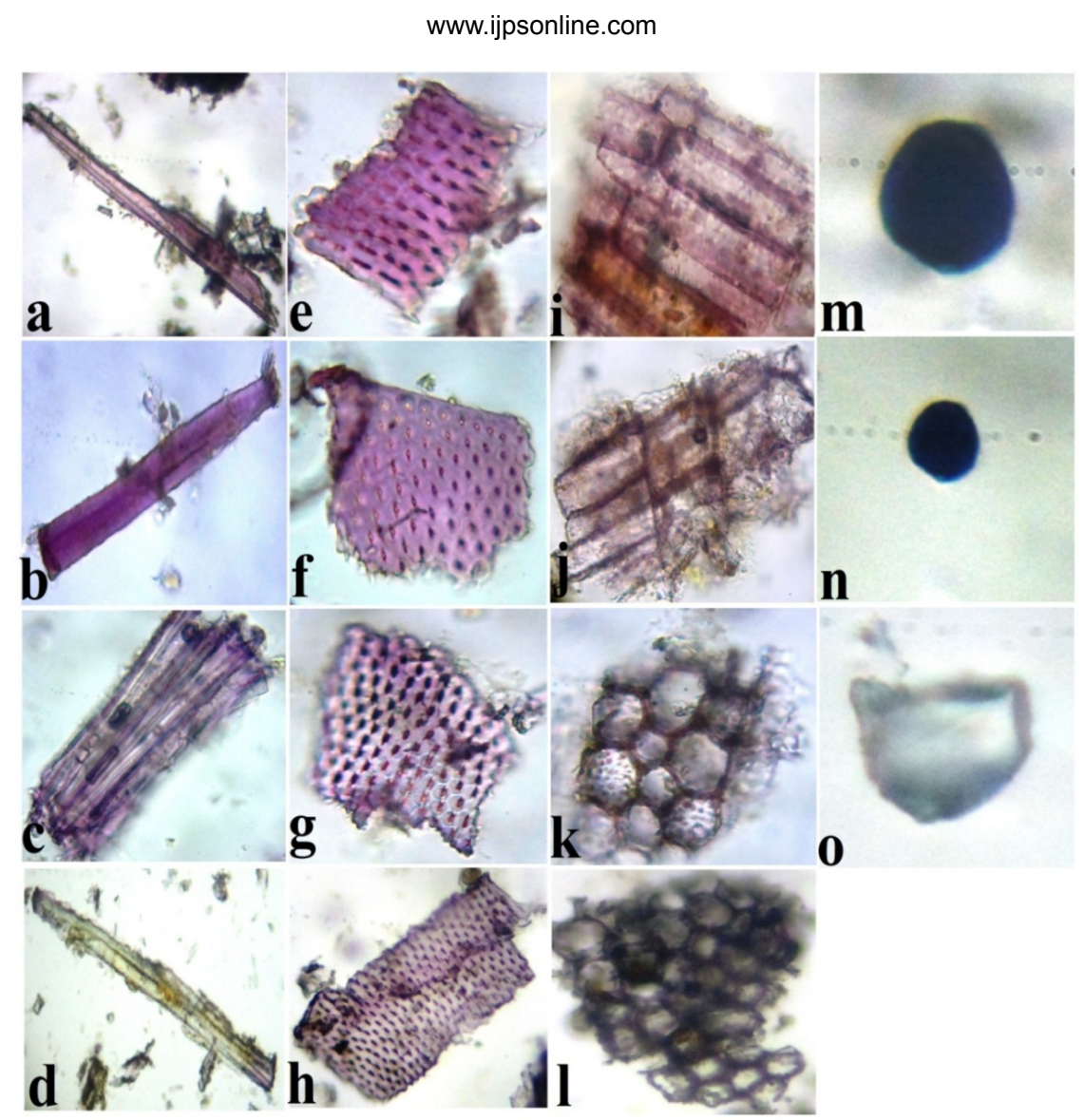

Fig. 2: (a, b and c) Lignified phloem fiber; (d) Non lignified phloem fibre; (e, $f, g$ and $h$ ) Pitted xylem vessels; (i and j) Fragments of cork; (k and l) Fragments of cortex; ( $m$ and $n$ ) Starch grains; (o) Prismatic calcium oxalate crystal

TABLE 1: ORGANOLEPTIC CHARACTERISTIC OF UDUMBARA GHANASATWA

\begin{tabular}{lc}
\hline Organoleptic character & Udumbara Ghanasatwa \\
\hline Appearance & Slightly sticky granular powder \\
Colour & Dark yellow \\
Odour & Earthy \\
Taste & Slightly Bitter and salty \\
\hline
\end{tabular}

the Ghanasatwa contained a high amount of tannin estimated to be $57.33 \pm 1.51 \mathrm{mg} \mathrm{TAE} / \mathrm{g}$.

Acute toxicity study results were discussed below. The Ghanasatwa neither altered the general behavior of animals nor did it produce any mortality up to the highest tested dose i.e., $2000 \mathrm{mg} / \mathrm{kg}$. This indicated the oral median Lethal Dose $50\left(\mathrm{LD}_{50}\right)$ of the product in rats was greater than $2000 \mathrm{mg} / \mathrm{kg}$, p.o.

There was clear evidence of a significant anti-secretary effect of the Ghanasatwa, compared to the control group, indicated by the decrease in gastric juice volume in the product-treated animals (Table 2). The elevation in $\mathrm{pH}$ in Ghanasatwa treated animals proved its ability to reduce gastric juice acidity. The Ghanasatwa was capable of reducing the gastric free acidity as well total acidity dose-dependently. The significant antiulcer effect was also observed in animals orally administered with standard drug ranitidine $(50 \mathrm{mg} / \mathrm{kg})$. Pylorus ligation had produced ulcers in all the control group rats with the lesion index value of $8.60 \pm 0.69$. The lesion index showed a dose-dependent reduction in the Ghanasatwa treated animals with $31.4 \%$ and $58.1 \%$ protection by lower and higher doses respectively (Table 2 and fig. 3). However, the standard anti-ulcer drug ranitidine provided $73.2 \%$ protection against pylorus ligation induced ulceration.

In the castor oil-induced diarrhoeal experiment, the Ghanasatwa dose-dependently reduced the number of diarrhoeal faeces and the total amount of faeces (Table 3). The reduction in faecal matter exhibited by the higher dose of the product (49.34\%) was also comparable with the inhibition observed for the reference drug loperamide (55.63\%). Furthermore, the Ghanasatwa dose-dependently inhibited castor oil induced enteropooling comparable to that of the standard drug loperamide (Table 4).

Udumbara Ghanasatwa, mentioned in the Ayurvedic text Bhaishajya Kalpana Vijnanam, is prescribed by Ayurveda practitioners for treating diarrhoeal and gastric ulcers without any scientific evidence. Hence, this present study was carried out to justify the use of 
TABLE 2: EFFECT OF UDUMBARA GHANASATWA AGAINST PYLORUS LIGATION-INDUCED GASTRIC ULCER MODEL IN RATS

\begin{tabular}{lccccccc}
\hline Groups & Treatment & $\begin{array}{c}\text { Dose } \\
(\mathrm{mg} / \mathrm{kg})\end{array}$ & $\begin{array}{c}\text { Gastric juice } \\
\text { volume }(\mathrm{ml})\end{array}$ & $\mathrm{pH}$ & $\begin{array}{c}\text { Free acidity } \\
(\mathrm{mEq} / 100 \mathrm{~g})\end{array}$ & $\begin{array}{c}\text { Total acidity } \\
(\mathrm{mEq} / 100 \mathrm{~g})\end{array}$ & Lesion index \\
\hline I & Control & - & $5.16 \pm 0.16$ & $3.68 \pm 0.108$ & $84.42 \pm 2.99$ & $101.56 \pm 1.86$ & $8.60 \pm 0.69$ \\
II & Ranitidine & 50 & $3.08 \pm 0.12^{* *}$ & $4.92 \pm 0.12^{* *}$ & $36.16 \pm 1.66^{* *}$ & $54.42 \pm 1.67^{* *}$ & $2.30 \pm 0.41^{* *}$ \\
III & Ghanasatwa & 200 & $4.16 \pm 0.10^{* *}$ & $3.84 \pm 0.11$ & $49.58 \pm 3.28^{* *}$ & $73.90 \pm 2.68^{* *}$ & $5.90 \pm 0.37^{* *}$ \\
IV & Ghanasatwa & 400 & $3.26 \pm 0.23^{* *}$ & $4.36 \pm 0.26^{*}$ & $41.60 \pm 3.61^{* *}$ & $62.92 \pm 1.86^{* *}$ & $3.60 \pm 0.33^{* *}$ \\
\hline
\end{tabular}

Note: Values are expressed as Mean \pm Standard Error of the Mean (SEM) $(n=5),{ }^{* *} p<0.01$ and ${ }^{*} p<0.05$ compared with vehicle control (ANOVA followed by post-hoc Tukey HSD test)
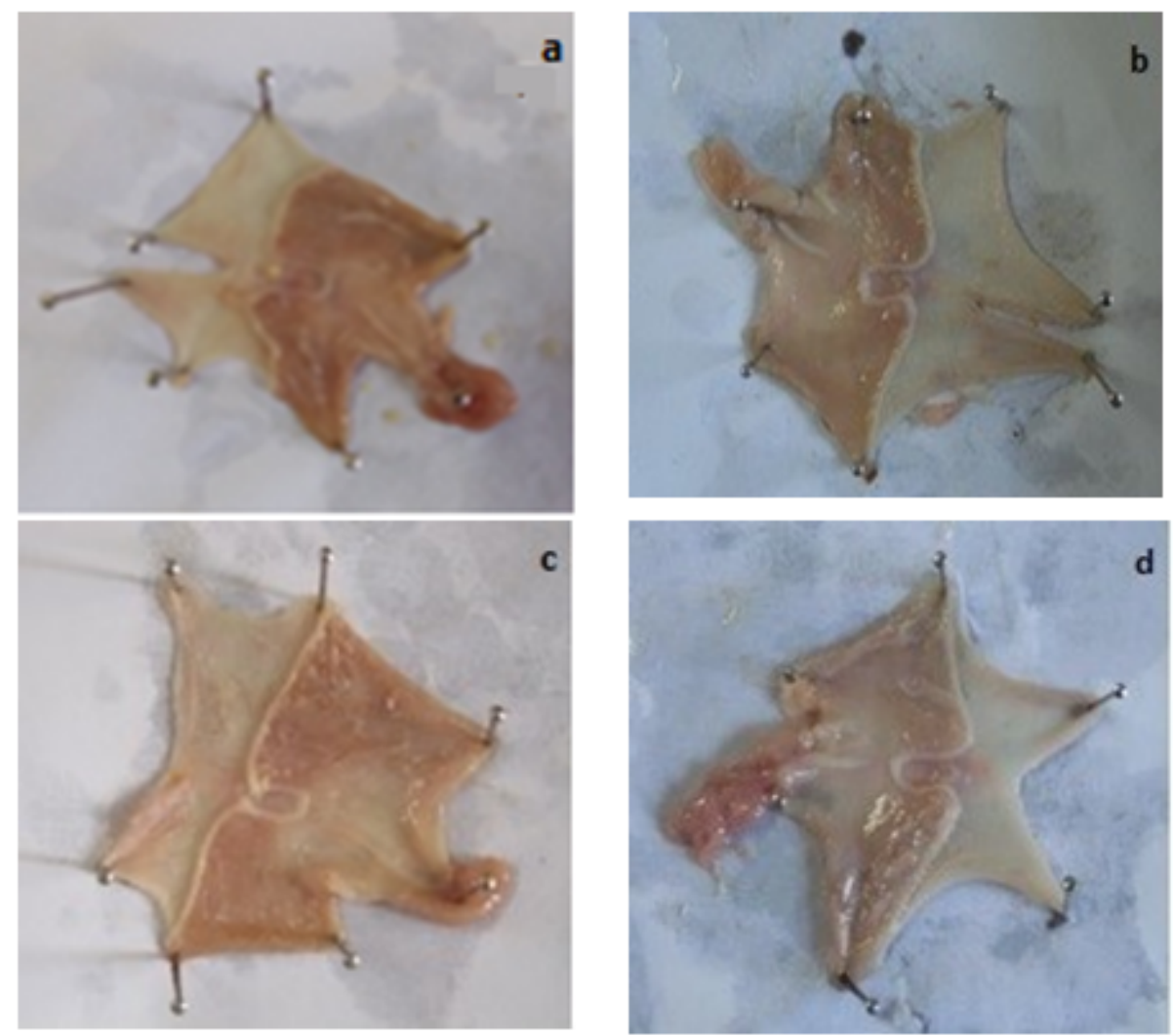

Fig. 3: Effect of Udumbara Ghanasatwa on pyloric ligation induced ulcers in the rats in the study, (a) Control; (b) Ranitidine (50 $\mathrm{mg} / \mathrm{kg}$ ) treated group; (c) Formulation, low dose (200 mg/kg) treated group (D) Formulation, low dose (400 mg/kg) treated group

\section{TABLE 3: EFFECT OF UDUMBARA GHANASATWA ON CASTOR OIL INDUCED DIARRHOEA IN RATS}

\begin{tabular}{lcccc}
\hline Group & Treatment & $\begin{array}{c}\text { Total number of } \\
\text { diarrhoeal faeces }\end{array}$ & $\begin{array}{c}\text { Total amount of } \\
\text { faeces }(\mathrm{g})\end{array}$ & $\begin{array}{c}\text { Percentage of inhibition } \\
\text { of faecal matter }\end{array}$ \\
\hline I & Castor oil+vehicle & $10.60 \pm 0.40$ & $6.04 \pm 0.45$ & - \\
II & Castor oil+loperamide (3 mg/kg orally) & $4.60 \pm 0.51^{* *}$ & $2.68 \pm 0.21^{* *}$ & 55.63 \\
III & Castor oil+Ghanasatwa (200 mg/kg orally) & $7.80 \pm 0.49^{* *}$ & $4.86 \pm 0.34$ & 19.54 \\
IV & Castor oil+Ghanasatwa (400 mg/kg orally) & $5.60 \pm 0.40^{* *}$ & $3.06 \pm 0.23^{* *}$ & 49.34 \\
\hline
\end{tabular}

Note: Values are expressed as Mean $\pm \operatorname{SEM}(n=5),{ }^{* *} \mathrm{p}<0.01$ and ${ }^{*} \mathrm{p}<0.05$ compared with vehicle control (ANOVA followed by post-hoc Tukey HSD test)

this Ayurvedic formulation as an anti-diarrhoeal and anti-ulcer drug.

Standardization of any herbal product is essential for the assurance of its consistent quality, biological activity and safety during its commercial manufacturing. Hence, some basic characterization of Udumbara Ghanasatwa was performed to confirm its identity, quality and purity.
The characteristic features of the histological section of fresh plant materials in combination with powder microscopic studies are very useful diagnostic tools for the standardization of crude drugs and identification of their adulterants. Therefore, microscopic features of the starting materials of Udumbara Ghanasatwa i.e., the fresh root bark of $F$. racemosa as well as powder 
TABLE 4: EFFECT OF UDUMBARA GHANASATWA ON CASTOR OIL INDUCED ENTEROPOOLING IN RATS

\begin{tabular}{lccc}
\hline Group & Treatment & Volume of intestinal fluid $(\mathrm{ml})$ & Percentage of inhibition \\
\hline I & Castor oil+vehicle $(2 \mathrm{ml} / \mathrm{kg}$ orally) & $5.86 \pm 0.25$ & - \\
II & Castor oil+loperamide $(3 \mathrm{mg} / \mathrm{kg}$ orally) & $2.58 \pm 0.18^{* *}$ & 55.97 \\
III & Castor oil+Ghanasatwa $(200 \mathrm{mg} / \mathrm{kg}$ orally) & $3.90 \pm 0.23^{* *}$ & 33.45 \\
IV & Castor oil+Ghanasatwa (400 mg/kg orally) & $3.12 \pm 0.14^{* *}$ & 46.76 \\
\hline
\end{tabular}

post-hoc Tukey HSD test)

Note: Values are expressed as Mean $\pm \operatorname{SEM}(n=5),{ }^{* *} p<0.01$ and ${ }^{*} p<0.05$ compared with vehicle control (ANOVA followed by

microscopic analysis of Udumbara churna were documented.

The establishment of pharmacognostic standards of herbal products facilitates the evaluation of consistency and quality in their commercial manufacturing. As the deviation in organoleptic characteristics gives a primary indication of quality variation, Udumbara Ghanasatwa was characterized by organoleptic parameters like appearance, colour, odour and taste. In the phytochemical screening, the Ghanasatwa was found to contain phytoconstituents like carbohydrates, alkaloids, glycoside, saponins and phenolic compounds like flavonoids and tannins. The presence of these constituents may be essential for the therapeutic effect of this product.

DPPH radical scavenging assay is a widely used test for evaluating the capacity of drugs to act as free radical scavengers or hydrogen donors ${ }^{[15]}$. The assay is based on the evaluation of the ability of the compounds to decolorize DPPH free radicals through scavenging. The activity parameter $\mathrm{IC}_{50}$, used for the interpretation of the results, is the concentration of substrate that causes a $50 \%$ loss of the DPPH activity. The reasonably lower $\mathrm{IC}_{50}$ value of the Ghanasatwa for DPPH free radical scavenging indicated its high antioxidant activity.

Dietary antioxidants have beneficial effects on human health and disease prevention. They inhibit the oxidation of biomolecules by free radical scavenging and help in repairing the damaged body tissues caused by oxidation injuries. Many herbal drugs containing a high amount of antioxidant phytoconstituents can reduce the risk of many chronic diseases in which antioxidants play a major role ${ }^{[16]}$.

It is a known fact the antioxidant effect of most herbal drugs is due to the presence of phenolic compounds such as flavonoids, polyphenols, tannins and phenolic terpenes ${ }^{[17]}$. Many plantderived antioxidants, especially polyphenols and flavonoids are used in treating diseases like cancer, diabetes and aging ${ }^{[18]}$. The beneficial effects of these phenolic compounds are the result of their antioxidant capacity, particularly free radicals scavenging by their hydroxyl groups and their ability to chelate metal cations. The presence of the higher amount of phenolic compounds found in Udumbara Ghanasatwa may be contributed to its high total antioxidant activity.

Flavonoids are naturally occurring polyphenolic compounds with considerable effects on human health. They exert a broad spectrum of biological activities including radical scavenging activity ${ }^{[19]}$. Flavonoids are capable of scavenging eventually every known reactive oxygen species. The presence of flavonoids in the Udumbara Ghanasatwa, could have therefore contributed to its free radical scavenging ability.

Tannins are complex polyphenol structures produced by most plants with free radical scavenging activity ${ }^{[20]}$. The herbs containing tannins are used in traditional medicines for treating diarrhoea and other diseases of the digestive tract ${ }^{[21]}$. The large quantity of tannins found in Udumbara Ghanasatwa may have resulted in its free radical scavenging, anti-inflammatory and anti-ulcer activities.

The results of the acute toxicity study of Udumbara Ghanasatwa advocated the safety of the oral administration of the drug in its therapeutic dose. The Ghanasatwa neither altered the general behaviour of animals nor did it produce any mortality up to the dose of $2000 \mathrm{mg} / \mathrm{kg}$. Based on this acute toxicity study, two different doses $(200 \mathrm{mg} / \mathrm{kg}$ and $400 \mathrm{mg} / \mathrm{kg})$ were selected for evaluation of its anti-diarrhoeal and antiulcer activity.

Peptic ulcer diseases, such as gastric and duodenal ulcers, are a very common global problem affecting millions of people worldwide ${ }^{[22]}$. Therapy for these disorders is directed towards the correction of the imbalance between acid and pepsin activity and enhancement in mucosal resistance. The success of therapy is measured in terms of symptom control, ulcer healing and delay in relapse rate. 
In the pylorus ligation model, the ulcer is induced by the accumulation of gastric acid and pepsin in the stomach causing auto-digestion of gastric mucosa and breakdown of its barrier ${ }^{[23]}$. The drugs which reduce gastric acid secretion are effective in ulcers induced by this model. The Ghanasatwa attenuated the pylorus ligation-induced increase in gastric volume, free acidity, total acidity and lesion index in rats by the antisecretory mechanism. This observed protection against the pylorus ligation-induced gastric ulcers may be the result of the cytoprotective action of the Ghanasatwa via an antioxidant mechanism attributed to the presence of phenolic compounds like flavonoids and tannins. These phenolic compounds have been reported to exert a beneficial effect in gastric ulcers by acting as a stimulator of mucous bicarbonate, an inhibitor of prostaglandin secretion and counteracting the liberating effect of reactive oxygen species in the gastrointestinal lumen $^{[24]}$. The results of this experiment thus justified the traditional use of Udumbara Ghanasatwa in ulcer treatment.

Diarrhoea is caused by the frequent passage of semisolid or liquid faecal material through the gastrointestinal tract. Some diarrhoea's are predominately secretory, while other diarrhoea's are induced by hypermotility. Secretory diarrhoea occurs due to an imbalance between absorption and secretion in the small intestine $^{[25]}$. On administration of castor oil, its active metabolite ricinoleic acid produces irritation and inflammation of the intestinal mucosa. This increases prostaglandin release, enhances peristalsis and decreases reabsorption of electrolytes and water from the intestine ${ }^{[26]}$. Loperamide is used as a standard anti-diarrhoeal drug, reduces the faecal volume and decreases fluid and electrolyte loss from the gut. It also possesses anti-secretory activity as an opiate receptor agonist of the intestinal myenteric plexus ${ }^{[27]}$. Our results suggested that the Udumbara Ghanasatwa prevented castor oil induced diarrhoea by inhibition of fluid accumulation in the small intestine through its antisecretory activity. Phenolic phytoconstituents such as tannins and flavonoids are known to inhibit castor oil induced release of prostaglandins, which in turn reduce motility and secretion of the gut ${ }^{[28]}$. The high amount of tannates in the Udumbara Ghanasatwa could also have helped in increasing the resistance of intestinal mucosa by protein denaturation ${ }^{[29]}$.

Findings obtained in our study, therefore, justified the credibility of Udumbara Ghanasatwa in its clinical applications as an anti-ulcer and anti-diarrhoeal agent.
These pharmacological activities may have resulted from its antioxidant potential. However, further studies are required to identify the specific bioactive components present in this herbal drug.

\section{Conflict of interests:}

The authors declared no conflict of interest.

\section{REFERENCES}

1. Tangjitman K, Wongsawad C, Kamwong K, Sukkho T, Trisonthi C. Ethnomedicinal plants used for digestive system disorders by the Karen of northern Thailand. J Ethnobiol Ethnomed 2015;11(1):1-3.

2. Rao GP. A text book of Bhaishajya Kalpana Vijnanam. New Delhi: Chaukhamba Publications; 2008. p. 248-49.

3. Shiksharthi AR, Mittal S. Ficus racemosa: Phytochemistry, traditional uses and pharmacological properties: A review. Int J Recent Adv Pharm Res 2011;4:6-15.

4. Das CH, Debta PR, Das DE, Ghosh GO. Cytomorphological and physico-chemical studies of Sida rhombifolia. Int J Pharm Pharm Sci 2015;7(10):46-56.

5. The Ayurvedic Pharmacopoeia of India, Part 2. 1st ed. New Delhi: Government of India, Ministry of Health and Family Welfare, Department of Ayush; 2008.

6. Mukhi S, Bose A, Ray A, Swain PK. Analytical standards of Amrtadi Churna: A classical ayurvedic formulation. Indian J Pharm Sci 2017;79(2):227-40.

7. Mukhi S, Bose A, Panda P, Rao MM. Pharmacognostic, physicochemical and chromatographic characterization of Samasharkara churna. J Ayurveda Integr Med 2016;7(2):8899.

8. Biglari F, AlKarkhi AF, Easa AM. Cluster analysis of antioxidant compounds in dates (Phoenix dactylifera): Effect of long-term cold storage. Food Chem 2009;112(4):998-1001.

9. Zhishen J, Mengcheng T, Jianming W. The determination of flavonoid contents in mulberry and their scavenging effects on superoxide radicals. Food Chem 1999;64(4):555-9.

10. CI KC, Indira G. Quantitative estimation of total phenolic, flavonoids, tannin and chlorophyll content of leaves of Strobilanthes kunthiana (Neelakurinji). J Med Plants 2016;4:282-6.

11. Mondal S, Ghosh D, Sagar N, Ganapaty S. Evaluation of antioxidant, toxicological and wound healing properties of Hibiscus rosa-sinensis L.(Malvaceae) ethanolic leaves extract on different experimental animal models. Indian J Pharm Edu Res 2016;50(1):620-37.

12. Bose A, Sahoo M, Ray SD. In vivo evaluation of anti-diarrheal activity of the rhizome of Nymphaea alba (Nymphaeaceae). Orient Pharm Exp Med 2012;12(2):129-34.

13. Sakat SS, Tupe P, Juvekar A. Gastroprotective effect of Oxalis corniculata (whole plant) on experimentally induced gastric ulceration in Wistar rats. Indian J Pharm Sci 2012;74(1):48-53.

14. Souza SM, Aquino LC, Jr AM, Bandeira MA, Nobre ME, Viana GS. Antiinflammatory and antiulcer properties of tannins from Myracrodruon urundeuva Allemão (Anacardiaceae) in rodents. Phytother Res 2007;21(3):220-5.

15. Jao CL, Ko WC. 1, 1-Diphenyl-2-picrylhydrazyl (DPPH) radical scavenging by protein hydrolyzates from tuna cooking juice. Fish Sci 2002;68(2):430-5.

16. Mallick M, Bose A, Mukhi S. Comparative evaluation of the antioxidant activity of some commonly used spices. Int $\mathrm{J}$ 
Pharmtech Res 2016;9(1):1-8.

17. Rahman MA, Moon SS. Antioxidant polyphenol glycosides from the plant Draba nemorosa. Bull Korean Chem Soc 2007;28(5):827-31.

18. Prasad KN, Yang B, Dong X, Jiang G, Zhang H, Xie H, et al. Flavonoid contents and antioxidant activities from Cinnamomum species. Innov Food Sci Emerg Technol 2009;10(4):627-32.

19. Amarowicz R, Pegg RB, Rahimi-Moghaddam P, Barl B, Weil JA. Free-radical scavenging capacity and antioxidant activity of selected plant species from the Canadian prairies. Food Chem 2004;84(4):551-62.

20. Hagerman AE, Riedl KM, Jones GA, Sovik KN, Ritchard NT, Hartzfeld PW, et al. High molecular weight plant polyphenolics (tannins) as biological antioxidants. J Agric Food Chem 1998;46(5):1887-92.

21. Ren A, Zhang W, Thomas HG, Barish A, Berry S, Kiel JS, et al. A tannic acid-based medical food, Cesinex ${ }^{\circledR}$, exhibits broadspectrum antidiarrheal properties: A mechanistic and clinical study. Dig Dis Sci 2012;57(1):99-108.

22. Alkofahi A, Atta AH. Pharmacological screening of the antiulcerogenic effects of some Jordanian medicinal plants in rats. J Ethnopharmacol 1999;67(3):341-5.
23. Goyal RK, Sairam K. Anti-ulcer drugs from indigenous sources with emphasis on Musa sapientum, Tamrabhasma, Asparagus racemosus and Zingiber officinale. Indian J Pharmacol 2002;34(2):100-10.

24. Sachin SS, Archana J. Antiulcer activity of methanol extract of Erythrina indica Lam. leaves in experimental animals. Pharmacognosy Res 2009;1(6):396-401.

25. Thiagarajah JR, Donowitz M, Verkman AS. Secretory diarrhoea: Mechanisms and emerging therapies. Nat Rev Gastroenterol Hepatol 2015;12(8):446-57.

26. Pérez Gutiérrez S, Zavala Mendoza D, Soto Peredo C, Sánchez Sánchez O, Zavala Sánchez MA. Evaluation of the anti-diarrheal activity of Salvia connivens. Pharm Biol 2014;52(11):1467-70.

27. Bafna P, Bodhankar S. Gastrointestinal effects of Mebarid ${ }^{\circledR}$, an ayurvedic formulation, in experimental animals. $J$ Ethnopharmacol 2003;86(2):173-6.

28. Veiga Jr VF, Zunino L, Calixto JB, Patitucci ML, Pinto AC. Phytochemical and antioedematogenic studies of commercial copaiba oils available in Brazil. Phytother Res 2001;15(6):47680.

29. Dey SK, Hira A, Howlader MS, Ahmed A, Hossain H, Jahan IA. Antioxidant and antidiarrheal activities of ethanol extract of Ardisia elliptica fruits. Pharm Biol 2014;52(2):213-20. 